ano 15 - n. 61 I julho/setembro - 2015

Belo Horizonte I p. 1-270 I ISSN 1516-3210

A\&C - R. de Dir. Administrativo \& Constitucional

Revista de Direito ADMINISTRATIVO \& CONSTITUCIONAL

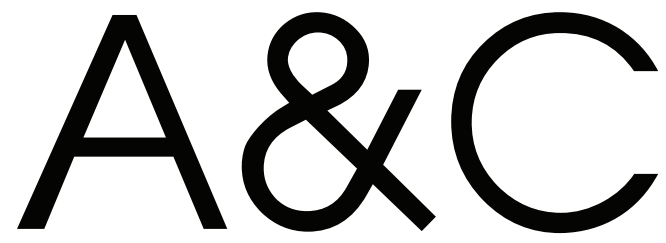




\section{A\&C - REVISTA DE DIREITO ADMINISTRATIVO \& CONSTITUCIONAL}

IPDA

Instituto Paranaense

de Direito Administrativo
ROMEU DEUPE

BACELLAR

๑) 2015 Editora Fórum Ltda.

Todos os direitos reservados. É proibida a reprodução total ou parcial, de qualquer forma ou por qualquer meio eletrônico ou mecânico, inclusive através de processos xerográficos, de fotocópias ou de gravação, sem permissão por escrito do possuidor dos direitos de cópias (Lei no 9.610, de 19.02.1998).

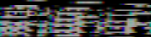

Luís Cláudio Rodrigues Ferreira

Presidente e Editor

Av. Afonso Pena, 2770 - 16ํandar - Funcionários - CEP 30130-007 - Belo Horizonte/MG - Brasil - Tel.: 08007043737 www.editoraforum.com.br / E-mail: editoraforum@editoraforum.com.br

Impressa no Brasil / Printed in Brazil / Distribuída em todo o Território Nacional

Os conceitos e opiniões expressas nos trabalhos assinados são de responsabilidade exclusiva de seus autores.

A246 A\&C : Revista de Direito Administrativo \&
Constitucional. - ano 3, n. 11, jan./mar.
2003)- . - Belo Horizonte: Fórum, 2003-
Trimestral
ISSN: 1516-3210
Ano 1, n. 1, 1999 até ano 2, n. 10, 2002 publicada
pela Editora Juruá em Curitiba
$\begin{aligned} & \text { 1. Direito administrativo. 2. Direito constitucional. } \\ & \text { I. Fórum. } \\ & \text { CDD: } 342 \\ & \text { CDU: } 342.9\end{aligned}$

Supenvisão editorial: Leonardo Eustáquio Siqueira Araújo

Capa: Igor Jamur

Projeto gráfico: Walter Santos

\section{Periódico classificado no Estrato A1 do Sistema Qualis da CAPES - Área: Direito.}

Revista do Programa de Pós-graduação do Instituto de Direito Romeu Felipe Bacellar (Instituição de Pesquisa e Pós-Graduação), em convênio com o Instituto Paranaense de Direito Administrativo (entidade associativa de âmbito regional filiada ao Instituto Brasileiro de Direito Administrativo). A linha editorial da $A \& C$ - Revista de Direito Administrativo \& Constitucional segue as diretrizes do Programa de Pós-Graduação do Instituto de Direito Romeu Felipe Bacellar em convênio com o Instituto Paranaense de Direito Administrativo. Procura divulgar as pesquisas desenvolvidas na área de Direito Constitucional e de Direito Administrativo, com foco na questão da efetividade dos seus institutos não só no Brasil como no direito comparado, com ênfase na questão da interação e efetividade dos seus institutos, notadamente América Latina e países europeus de cultura latina.

A publicação é decidida com base em pareceres, respeitando-se o anonimato tanto do autor quanto dos pareceristas (sistema double-blind peer review).

Desde o primeiro número da Revista, $75 \%$ dos artigos publicados (por volume anual) são de autores vinculados a pelo menos cinco instituições distintas do Instituto de Direito Romeu Felipe Bacellar.

A partir do volume referente ao ano de 2008 , pelo menos $15 \%$ dos artigos publicados são de autores filiados a instituições estrangeiras.

Esta publicação está catalogada em:

- Ulrich's Periodicals Directory

- RVBI (Rede Virtual de Bibliotecas - Congresso Nacional)

- Library of Congress (Biblioteca do Congresso dos EUA)

A\&C - Revista de Direito Administrativo \& Constitucional realiza permuta com as seguintes publicações: - Revista da Faculdade de Direito, Universidade de São Paulo (USP), ISSN 0303-9838

- Rivista Diritto Pubblico Comparato ed Europeo, ISBN/EAN 978-88-348-9934-2 
Diretor-Geral

Romeu Felipe Bacellar Filho

Diretor Editorial

Paulo Roberto Ferreira Motta

Editores Acadêmicos Responsáveis

Daniel Wunder Hachem

Ana Cláudia Finger

Assessor Editorial

Felipe Klein Gussoli

\section{Conselho Editorial}

Adilson Abreu Dallari (PUC-SP) Juan Pablo Cajarville Peluffo (Universidad de La República - Uruguai) ardo Schier (Instituto Bacellar) Justo J. Reyna (Universidad Nacional del Litoral - Argentina)

Alice Gonzalez Borges (UFBA) Juarez Freitas (UFRGS)

Carlos Ari Sundfeld (FGV-SP) Luís Enrique Chase Plate (Universidad Nacional de Asunción - Paraguai)

Carlos Ayres Britto (UFSE) Marçal Justen Filho (UFPR)

Adriana da Costa Ricardo Schier (Instituto Bacellar)
Alice Gonzalez Borges (UFBA)

Marcelo Figueiredo (PUC-SP)

Márcio Cammarosano (PUC-SP)

Carlos Delpiazzo (Universidad de La República - Uruguai) Cármen Lúcia Antunes Rocha (PUC Minas) Célio Heitor Guimarães (Instituto Bacellar) Celso Antônio Bandeira de Mello (PUC-SP) Clèmerson Merlin Clève (UFPR) Clovis Beznos (PUC-SP) Edgar Chiuratto Guimarães (Instituto Bacellar) Maria Cristina Cesar de Oliveira (UFPA)

Nelson Figueiredo (UFG)

Odilon Borges Junior (UFES)

Pascual Caiella (Universidad de La Plata - Argentina)

Emerson Gabardo (UFPR)

Paulo Eduardo Garrido Modesto (UFBA)

Paulo Henrique Blasi (UFSC)

Enrique Silva Cimma (Universidad de Chile - Chile) Eros Roberto Grau (USP)

Irmgard Elena Lepenies (Universidad Nacional del Litoral - Argentina) de La Coruña - Espanha)

Pedro Paulo de Almeida Dutra (UFMG)

Regina Maria Macedo Nery Ferrari (UFPR)

Rogério Gesta Leal (UNISC)

Rolando Pantoja Bauzá (Universidad Nacional de Chile - Chile)

Sergio Ferraz (PUC-Rio)

Valmir Pontes Filho (UFCE)

José Eduardo Martins Cardoso (PUC-SP)

José Luís Said (Universidad de Buenos Aires - Argentina) José Mario Serrate Paz (Universidad de Santa Cruz - Bolívia)

Yara Stroppa (PUC-SP)

\section{Homenagem Especial}

Guillermo Andrés Muñoz (in memoriam) Jorge Luís Salomoni (in memoriam) Julio Rodolfo Comadira (in memoriam) Lúcia Valle Figueiredo (in memoriam)

Manoel de Oliveira Franco Sobrinho (in memoriam) Paulo Neves de Carvalho (in memoriam) 


\title{
The Right to Information from the Procedural Standpoint (Judicial and Non-Judicial)*
}

\author{
Ricardo Perlingeiro \\ Full Professor at the Law School of Fluminense Federal University (UFF - Rio de Janeiro-RJ) and \\ coordinator of the Judiciary Sciences Centre at UFF (Nupej/UFF). Doctorate in Law - University \\ Gama Filho (UGF). Coordinator of the Executive Committee of the National Council of Justice for \\ the monitoring and settlement of healthcare assistance claims in the State of Rio de Janeiro. \\ Member of the Brazilian Institute of Procedural Law. Member of Ibero-American Institute of \\ Procedural Law. Member of the International Association of Procedural Law. Federal judge of the \\ Judiciary Section of Rio de Janeiro. E-mail: <r.perlingeiro@terra.com.br>.
}

\begin{abstract}
The author takes a general descriptive approach to the system of jurisdictional review of decisions concerning access to official information in Latin America, with the aim of enabling a future comparative administrative law study on information access in the People's Republic of China. The first two topics are related to an overview of the right to information access in Latin America and the corresponding laws, with imprecise rules that lead to behavior by the administrative authorities that is subject to review of dubious effectiveness, so that the authorities are verging on a state of immunity incompatible with the Rule of Law. The third part is about the developments in Latin America up to the present day, jurisdictional review (judicial and non-judicial) of administrative decisions not only in terms of their formal legality but, above all, their substantive legality, i.e., a review of the content of the administrative decisions, including the discretionary administrative powers and margin of administrative appreciation. The fourth topic, the due process clause, influenced by the USA, is discussed in the context of Latin American information access law, in comparison with the Continental European tradition of administrative law. The fifth and final point concerns the models of jurisdictional review of decisions on information access within the sphere of the OAS (Organization of American States) and Latin American countries. Among other conclusions, the author states that the search for an effective information access system that does not necessarily depend on opting for a model already established in Brazil, Latin America, the USA or Europe; what is of fundamental importance is to provide the interested parties with access to a fair trial guaranteeing their right to information access except in cases in which secrecy is necessary and justified according to the international human rights criteria.
\end{abstract}

Key words: Right to information access. Administrative jurisdiction. Due process of law. Latin America.

Summary: $\mathbf{1}$ Overview of the right to information access in Latin America - $\mathbf{2}$ Vague legal concept and vulnerability of information access law $\mathbf{-} \mathbf{3}$ Jurisdictional (judicial and non-judicial) review of the margin of administrative appreciation - $\mathbf{4}$ Procedural administrative due process of law in Latin America - $\mathbf{5}$ Models of review of decisions on information access within the sphere of the OAS and Latin American countries Closing considerations

On the topic of "the right to information from the procedural standpoint (judicial e non-judicial)", I will propose a general descriptive approach to the system of

\footnotetext{
* Text of a lecture given in the Center of Constitutional Law and Administrative Law of the Beijing University Law School in Beijing, People's Republic of China, 23 March 2015.
} 
jurisdictional review of decisions on information access in Latin America, with the aim of enabling a future comparative administrative law study on information access in the People's Republic of China.

The text is organized in five parts and a conclusion.

The first two topics are related to an overview of the right to information access in Latin America and the corresponding laws, with imprecise rules that lead to behavior by the administrative authorities that is subject to review of dubious effectiveness, so that the authorities are verging on a state of immunity incompatible with the Rule of Law.

The third part is about the developments in Latin America up to the present day, jurisdictional review (judicial and non-judicial) of administrative decisions not only in terms of their formal legality but, above all, their substantive legality, i.e., a review of the content of the administrative decisions, including the discretionary administrative powers and margin of administrative appreciation.

The fourth topic, the due process clause, influenced by the USA, is discussed in the context of Latin American information access law, in comparison with the Continental European tradition.

The fifth and final point concerns the models of jurisdictional review of decisions on information access within the sphere of the OAS (Organization of American States) and Latin American countries.

\section{Overview of the right to information access in Latin America}

The Inter-American Court of Human Rights, in its decision Claude Reyes and Others v. Chile of 2006, acknowledged the existence of a right of access to official information - to search for and receive information - based on Article 13 of the InterAmerican Human Rights Convention, on freedom of thought and expression.

In addition, a significant development in the subject in Latin America occurred in 2008, with the approval of the Principles on the Right of Access to Information of the Inter-American Juridical Committee of the OAS (Organization of American States). That document contains a declaration of ten principles governing the right to information, which is asserted to be fundamental human right applicable to all public bodies including the Legislative, Executive and Judicial branches - and all information. It further stipulates that exceptions must be defined clearly and narrowly, and that it must be possible to file an appeal with body of review in case of refusal of request for information.

In Brazil, the right to information access is enshrined in the 1988 Constitution, which stipulates that "all persons have the right to receive, from the public agencies, information of private interest to such persons, or of collective or general interest, which shall be provided within the period established by law, subject to liability, except 
for the information whose secrecy is essential to the security of society and of the State" (Article 50 XXXIII). The Brazilian Law on information access (Law 12.527/2011) confirms that information access is a fundamental right (Article $3^{\circ}$ ).

In Latin America, thirteen out of the nineteen States of Iberian origin already have general laws on the right to information access. They are: Mexico, Peru, Argentina, Ecuador, the Dominican Republic, Honduras, Nicaragua, Chile, Guatemala, Uruguay, El Salvador, Brazil and Colombia. Four out of the seven remaining countries are currently discussing a general legislative bill on information access: Bolivia, Costa Rica, Panama and Paraguay.

Within the sphere of the Inter-American System of Human Rights, particularly noteworthy is the Model Inter-American Law on Access to Public Information, which has had a very big influence on information access law in Latin America and was approved in 2010 by the plenary session of the OAS.

It is not difficult to understand why there is so much enthusiasm about the codes on information access: a branch of law which, until the end of the 1990s was practically unknown in the legal culture of most countries; a branch of law in which the State's duties of service are derived directly from international treaties and the Constitution, and which is therefore accompanied by a broad margin of interpretation; a branch of law in which the legislation is scant and unclear, in which the public authorities are broadening their margin of appreciation.

\section{Vague legal concept and vulnerability of information access law}

Despite the successful systematization of innumerable rules into general laws of information access in Latin America, some of them do not meet the expectations of a law code, especially in light of the socio-political reality of their countries.

I am referring to rules that are still very imprecise and subject to controversial interpretations by the public authorities, which almost never benefit from guarantees of independent action.

Good examples of this problem may be found in the limitations on information access which are usually justified on the basis of private interests, such as privacy, on the one hand, and on public interests, such as public safety or national defense, on the other.

Such rules contain terms that are hard to define precisely: privacy, public interest, public safety, national defense, etc. All of them require the authorities to make a constant effort of evaluation based on the principle of proportionality, as noted in the preamble to Article 40 of the already mentioned Model Inter-American Law. In fact, the principle of proportionality opens the door to innumerable exceptions (exceptions to the limits on the freedom of information) which can only be detected by the public authorities in each specific case. 
It is therefore advisable for the codes to modify the most sensitive rules which are open to fluid interpretation in such a way that the public authorities would feel themselves more strongly bound to a literal exegesis of the norms, providing greater legal certainty and, in a certain way, lending general credibility to the information access system.

The legal codes should anticipate abstract interpretations as much as possible (by providing definitions and clarifications) of vague legal concepts that end up being subject to the powers of appreciation of the public authorities.

In this context, in the absence of laws with the previously-described characteristics, the main point of discussion regarding procedural safeguards of the right to information in Latin America becomes the public authorities' ability to resort to the margin of appreciation regarding vague legal concepts - which are often invoked in order to restrict information access.

\section{Jurisdictional (judicial and non-judicial) review of the margin of administrative appreciation}

When administrative law first appeared in the 19th Century, there was a great deal of discussion about which acts of the public authorities could be questioned judicially. Initially, based on French law, the solution was to give the public authorities themselves the power to rule on conflicts originating in administrative acts, while leaving only "administrative litigation" to the law courts, which at the time was understood to mean private-law issues involving the administrative authorities. For a long time, the understanding was that private-law disputes should be handled by the Judiciary and public-law disputes by the Executive Branch.

Later on, in the late $19^{\text {th }}$ Century, public-law conflicts ceased to be resolved solely on the basis of the "power of administrative self-supervision" and also became subject to a jurisdiction independent from the authorities responsible for the challenged decision. At that point, it was not so important to know whether the review was judicial or nonjudicial, since, either way, independence was a hallmark of the jurisdictional function. Incidentally, that has been the tendency in the European and Inter-American Courts of Human Rights, by extending the guarantees of "due process of law" to non-judicial proceedings, which are to be conducted by impartial and independent authorities.

Throughout the $20^{\text {th }}$ Century, the doubt persisted about the possibility of (judicial or non-judicial) jurisdiction attaining to the decision-making margin of the authorities, which are: their discretionary powers, on the one hand, and the margins of appreciation of questions of fact and law, on the other. The question has been settled only recently. 
With respect to the discretionary administrative powers, it is currently understood that they are subject to review whenever they exceed the limits of the statute that granted them or when they violate fundamental rights or the principles of proportionality, equal treatment, protection of legitimate expectations or prohibition of arbitrary action.

The margins of administrative appreciation are now considered to be entirely subject to jurisdictional review: it is possible to challenge the administrative power to hear the facts of the case, the administrative power of legal evaluation of the facts and the administrative power of interpretation of the law.

\section{Procedural administrative due process of law in Latin America}

Originating in the Magna Carta of 1215, according to which no individual interest or right could be restricted by the State without a prior trial, the procedural due process of law developed in the USA (based on Fifth and Fourteenth Amendment) in such a way that administrative decisions restricting individual rights cannot be made without first granting the parties an opportunity to participate in a fair trial.

In fact, administrative due process of law corresponds to a primary administrative jurisdiction, that is to say, it is considered necessary to provide an effective trial presided over by a quasi-judicial (independent) authority as a condition precedent to the enforcement of any administrative decision restricting individual rights.

This US perspective has been formally adopted by the majority of the Constitutions of the Latin American States: Colombia, Brazil, Venezuela, Dominican Republic, Nicaragua, Ecuador, Mexico, Bolivia, Chile, Peru and Guatemala. The due process clause is also found in the legislation of Argentina and Uruguay.

In practice, however, the administrative law of all those countries is still much more closely tied to the Continental European tradition in that the effective jurisdiction is subsequent to the enforcement of the administrative decision, except in cases of interim relief in which the individual claim against the State benefits from the notions of fumus boni iuris (likelihood of success on the merits of the case) and periculum in mora (danger in delay).

\section{Models of review of decisions on information access within the sphere of the OAS and Latin American countries}

The Model Inter-American Law on Access to Public Information of 2010 proposes to the Latin American States to adopt a system of jurisdictional review of administrative decisions regarding information access that is focused on a non-judicial body and endowed with the prerogatives of independence relative to the authorities who hold the information. 
This model is followed by Mexico, with its Federal Institute of Information Access and Data Protection; Chile, with its Transparency Council; Honduras, with its Institute of Commissioners; and El Salvador, with its Institute of Public Information Access.

In fact, the model of non-judicial review of information access proposed by the OAS is similar to the administrative adjudication of the USA, by virtue of the quasi-judicial prerogatives held by its appellate administrative authorities, although the OAS model does not provide for a primary jurisdiction. In addition, although the OAS model does not restrict judicial review of the decisions delivered by the independent non-judicial bodies of review, it is common practice for the courts of those Latin American countries that adopt this model to recognize administrative deference in their favor due to the high degree of specialization and credibility of such bodies.

The majority of Latin American States, however, including Brazil, do not follow the model proposed by the Inter-American Commission on Human Rights of the OAS. Such countries generally observe the same rules applicable to the other administrative acts restricting individual rights, such as the prior administrative procedure that is conducted by non-independent authorities and is subject to full and effective judicial review subsequent to the enforcement of the challenged decision. This is the typical Continental European model of administrative law that is still firmly anchored in Latin-American law.

According to Brazilian legislation (Law 12.527/2011), any interested party may request access to public information; in case of refusal, the burden is on the relevant authority to justify its refusal when challenged by an appeal to a hierarchically superior authority. In the case of the federal government authorities (Administração Pública Federal), a decision refusing information access can be appealed to the Office of the Comptroller General (Controladoria-Geral da União), which is closely tied to the Office of the President of the Republic, or can be appealed to the Joint Committee on Information Disclosure, which is composed of representatives of the Ministries and other bodies connected with the Executive Branch. According to Brazilian case law, the non-judicial appeals and challenge are considered optional; the interested parties are entitled to call upon the jurisdiction of the courts at any time.

\section{Closing considerations}

The search for an effective information access system does not necessarily depend on opting for a model already established in Brazil, Latin America, the USA or Europe. The right to information access may be reviewed just as effectively by administrative authorities as by courts of law. A prior review of the effects of the administrative decision can satisfy the requirement of a fair trial just as well as can 
be done by an a posteriori review of the initial administrative decision. What is of fundamental importance is to provide the interested parties with access to a fair trial, guaranteeing their right to information access except in cases in which secrecy is necessary and justified according to the international human rights criteria. For that purpose, it is indispensable for authorities in charge of conducting the proceedings designed to review decisions on the right to information access to be impartial, independent and technically competent.

The more an administrative authority is endowed with those characteristics, the more restrict will be the range of action of the law courts; and vice-versa. In addition, as far as primary or a posteriori administrative jurisdiction is concerned, what is important is that the enforcement of any administrative decision on access information must always be preceded, in cases of risk or irreparable damage, by an opportunity for the interested party - through interim relief - to stay the execution of the decision by the administrative authorities or law courts.

This means that if there is no applicable pre-existing law, or if the existing law is unclear, legal certainty about the right to information access can be obtained by means of a fair trial.

It should be noted, however, that the more incisive the acts of the legislators, the less effort will be required of the administrative authorities and courts to decide on information access; and vice-versa.

\section{0 direito à informação do ponto de vista processual (judicial e extrajudicial)}

Resumo: O autor traz uma abordagem geral e descritiva do sistema de controle jurisdicional das decisões sobre acesso à informação oficial na América Latina, tendo em vista viabilizar, no futuro, um estudo comparado com o direito administrativo de acesso à informação na República Popular da China. Os dois primeiros tópicos se referem ao panorama latino-americano do direito de acesso à informação e sua legislação com regras imprecisas, que induzem a comportamentos de autoridades administrativas, os quais se sujeitam a um controle de duvidosa efetividade e, por tal razão, beiram a uma imunidade não compativel com o Estado de Direito. A terceira parte se refere à evolução na América Latina, até a presente data, do controle jurisdicional (judicial e extrajudicial) das decisões administrativas: não somente dos seus aspectos de legalidade formal, mas, sobretudo, de legalidade material, isto é, o controle dos aspectos de conteúdo das decisões administrativas, incluindo os poderes administrativos discricionários e a margem de apreciação administrativa. No quarto tópico, a cláusula do devido processo legal, de influência norteamericana, é contextualizada no direito latino-americano sobre acesso à informação, em confronto com a tradição europeia-continental. No quinto e último ponto, o autor discorre sobre os modelos de controle jurisdicional das decisões sobre acesso à informação no âmbito da OEA - Organização dos Estados Americanos e dos países latino-americanos. Dentre as suas conclusões, afirma o autor que a busca por um sistema de acesso à informação eficaz não dependente, necessariamente, da opção por um modelo preestabelecido no Brasil, na América Latina, nos EUA ou na Europa; o fundamental é estar ao alcance dos interessados um processo efetivo - materialmente jurisdicional - que Ihes traga garantias de que o direito de acesso à informação será observado, exceto quando o sigilo for necessário e justificado em parâmetros internacionais de direitos humanos.

Palavras-chave: Direito de acesso à informação. Jurisdição administrativa. Devido processo legal. América Latina. 
Informação bibliográfica deste texto, conforme a NBR 6023:2002 da Associação Brasileira de Normas Técnicas (ABNT):

PERLINGEIRO, Ricardo. The Right to Information from the Procedural Standpoint (Judicial and Non-Judicial). A\&C - Revista de Direito Administrativo \& Constitucional, Belo Horizonte, ano 15, n. 61, p. 43-50, jul./set. 2015.

Recebido em: 25.03.2015

Aprovado em: 17.05.2015 